\title{
SKETSA PEMIKIRAN KEAGAMAAN DALAM PERSPEKTIF NORMATIF, HISTORIS DAN SOSIAL-EKONOMI
}

\section{Andi Eka Putra}

Universitas Islam Negeri Raden Intan Lampung

andiekaputra@radenintan.ac.id

\begin{abstract}
Contemporary religious thought is open and plural. Various approaches have emerged from the oldest such as the historical approach to the latest such as the Islamic economic approach. various approaches to religious thought are often simply grouped into three main stream groups; namely the normative, historical and sociological groups. These three approaches are not infrequently fragmented, whereas ideally, as a religious thought, the three must be linked and combined to produce a multidisciplinary approach, namely an approach that comprehensively can refresh contemporary religious thought that seems to be sluggish.
\end{abstract}

\section{Abstrak}

Pemikiran keagamaan kontemporer bersifat terbuka dan plural. Berbagai pendekatan bermunculan mulai dari yang paling tua seperti pendekatan historis bingga yang paling belakangan seperti pendekatan ekonomi Islam. berbagai pendekatan pemikiran keagamaan seringkali dikelompkekan secara sederhana ke dalam tiga kelompok arus utama; yakni kelmpok normatif, historis, dan sosiologis. Ketiga pendekatan ini tak jarang terpisab-pisah, padahal idealnya, sebagai sebuah pemikiran keagamaan, ketiganya mesti dapat dipertautkan dan dikombinasikan sehingga menghasilkean suatu pendekatan multidisipliner, yakni pendekatan yang secara komprehensif dapat menyegarkan kembali pemikiran keagamaan kontemporer yang tampak mulai lesu. 
Keywords: Religious thought, normative approach, historical and socioeconomic

\section{A. Pendahuluan}

Perkembangan pemikiran keagamaan dalam Islam di Indonesia akhir-akhir ini amat menarik untuk diamati. Berbagai pendekatan dan perspektif diajukan untuk menganalisis perkembangan pemikiran keagamaan mutakhir. Di antara perkembangan pemikiran keagamaan tersebut, yang paling menonjol adalah pemikiran keagamaan bercorak normatif, historis dan sosial ekonomi.

Makalah ini akan mendeskripsikan sketsa pemikiran keagamaan kontemporer tersebut secara singkat untuk melihat perbedaan dan keragaman masing-masing pendekatan. Masingmasing akan dideskripsikan secara singkat untuk kemudian dianalisis.

\section{B. Pendekatan Normatif}

Sesuai dengan istilahnya, kata "normatif" berasal dari bahasa Inggris, norm, yang berarti norma, ajaran, acuan, ketentuan tentang masalah yang baik dan buruk, yang boleh dilakukan dan yang tidak boleh dilakukan. Dalam hubungan ini kata norma erat hubungannya dengan akhlak, yaitu perbuatan yang muncul dengan mudah dari kesadaran jiwa yang bersih dan dilakukan atas kemauan sendiri, bukan berpura-pura dan bukan pula paksaan. Selanjutnya karena akhlak, merupakan inti dari agama, bahkan inti ajaran al-Qur'an, maka norma sering diartikan pula agama. karena agama tersebut berasal dari Allah, dan sesuatu yang berasal dari Allah pasti benar adanya, maka norma tersebut juga diyakini pasti benar adanya, tidak boleh dilanggar dan wajib dilaksanakan. ${ }^{1}$

Ada juga istilah yang berdekatan dengan kata normatif, yaitu normativitas, sebagai kata sifat dari norma. Dalam pemikiran Islam

\footnotetext{
1 Abuddin Nata, Peta Keragaman Pemikiran Islam di Indonesia Jakarta: PT RajaGrafindo, 2001), h. 18
} 
kontemporer, terdapat suatu pendekatan yang kemudian populer disebut pendekatan normatif yang berlandaskan norma-norma keagamaan. Pendekatan normatif adalah pendekatan yang memandang agama dari segi ajarannya yang pokok dan asli dari Tuhan yang di dalamnya belum terdapat pemikiran manusia. Pendekatan ini bersifat tekstual dan kurang memberi ruang terhadap kntekstualitas pemikiran.

Dalam pendekatan normatif ini, teks agama dilihat sebagai suatu kebenaran yang mutlak dari Tuhan yang di dalamnya belum terdapat penalaran pemikiran manusia. Kebenaran diukur berdasarkan nash atau teks yang sifatnya qat'i atau mutlak. ${ }^{2}$

Dengan kata lain, pendekatan normatif merupakan pendekatan legal-formal. Maksudnya yaitu pendekatan yang masih bersifat rigid, kaku, mengandung kemutlakan ajaran atau hukum yang ada hubungannya dengan halal dan haram, boleh atau tidak dan sejenisnya. Sementara normatif di sini yaitu seluruh ajaran yang terkandung dalam nash.

Dengan demikian, pendekatan normatif mempunyai cakupan yang sangat luas sebab seluruh pendekatan yang digunakan oleh ahli usul fikih (usuliyin), ahli hukum islam (fuqaha), ahli tafsir (mufassirin) dan ahli hadits (muhaddithin) ada hubungannya dengan aspek legalformal serta ajaran Islam dari sumbernya termasuk pendekatan normatif. ${ }^{3}$

Sisi lain dari pendekatan normatif, secara umum, mengandung dua unsur teori yang dapat digunakan bersama pendekatan normatif-teologis. Teori yang pertama adalah hal-hal yang bertujuan untuk mengetahui kebenaran serta dapat dibuktikan secara empirik dan eksperimental.Teori yang kedua adalah hal-hal yang sulit dibuktikan secara empirik dan eksperimental.Untuk hal-hal yang dapat dibuktikan secara empirik biasanya disebut masalah yang berhubungan dengan ra'yi (penalaran).

Sedang masalah-masalah yang tidak berhubungan dengan empirik (ghaib) biasanya diusahakan pembuktiannya dengan

\section{Ibid., h. 28}

${ }^{3}$ Khoiruddin Nasution, Pengantar Studi Islam, Yogyakarta: Academia dan Tazzafa, 2009, h. 197 
mendahulukan kepercayaan. Hanya saja cukup sulit untuk menentukan hal-hal apa saja yang masuk klasifikasi empirik dan mana yang tidak terjadi sehingga menyebabkan perbedaan pendapat dikalangan para ahli.Maka sikap yang perlu dilakukan dengan pendekatan normatif adalah sikap kritis.

Kalau ada istilah Islam Normatif, ini mesti di maknai sebagai Islam yang datang memuat nilai-nilai, aturan, etika yang murni dari Tuhan tanpa adanya intervensi manusia. Islam Normatif memuat seperangkat nilai-nilai yang kebenarannya absolut. Pada umumnya, normativitas ajaran wahyu (teologis-normatif) dibangun, diramu, dibakukan, dan ditelaah lewat pendekatan doktrinal-teologis. Pendekatan ini berangkat dari teks yang sudah ditulis dalam kitab suci.

Teologi adalah pemikiran tentang persoalan ketuhanan. Contoh persoalan ketuhanan diantaranya adalah adanya nabi palsu dan manusia pada umumnya dapat mempercayainya. Untuk mengatasi hal tersebut seseorang harus mengetahui arti dari islam normatif dan historis dengan sesungguhnya.

Pendekatan normatif ini melahirkan tradisi teks : tafsir, teologi, fiqh, tasawuf, filsafat. ${ }^{4}$ Karena dalam perkembangannya dianggap kaku, keras, rigid, maka muncul kritik atas pendekatan ini.

\section{Pendekatan Historis}

Pendekatan historis atau sejarah adalah pendekatan yang muncul sebagai kritik atas pendekatan normatif. Menurut M. Yatimin Abdullah, tujuan pendekatan historis atau sejarah dalam pengkajian Islam adalah untuk merekonstruksi masa lampau secara sistematis dan objektif dengan cara mengumpulkan, mengevaluasi, memverifikasi, serta mensistematisasikan bukti-bukti untuk menegakkan fakta dan memperoleh kesimpulan yang kuat. ${ }^{5}$

Yatimin menambahkan bahwa dengan berbagai pendekatan manusia dalam memahami agama dapat melalui pendekatan 2006, h.222

${ }^{4}$ M .Yatimin Abdullah, Studi Islam Kontemporer,Jakarta:Sinar Grafika Offset,

${ }^{5}$ Ibid., h. 58-59 
paradigma ini. Dengan pendekatan ini semua orang dapat sampai pada agama. Disini dapat dilihat bahwa agama bukan hanya monopoli kalangan teolog dan normalis, melainkan agama dapat dipahami semua orang sesuai dengan pendekatan dan kesanggupannya. Oleh karena itu, agama hanya merupakan hidayah Allah dan merupakan suatu kewajiban manusia sebagai fitrah yang diberikan Allah kepadanya. ${ }^{6}$

Pemahaman terhadap ilmu sejarah menjadi penting bagi kalangan intelektual hukum (Islam) untuk melihat mata rantai antara satu kejadian dan kejadian lain sehingga tidak terjadi distorsi dalam menjustifikasi sebuah peristiwa hukum. Begitu pula, kajian sejarah menjadi alat ukur bagi kalangan intelektual dari berbagai disiplin ilmu dalam memilih dan memilah masalah. ${ }^{7}$

Memahami pendekatan historis tidak bisa lepas dari memahami terlebih dahulu akan makna kata tersebut. Kata historis memiliki kedekatan dengan kata History dalam bahasa Inggris yang memiliki makna sejarah (dalam bahasa arab Syajarah). Kata tersebut diambil dari bahasa Yunani (istoria), yakni gejala-gejala alam yang bersifat kronologis terutama yang berkaitan dengan manusia. Di sini sejarah merupakan ilmu pengetahuan sebagai upaya melukiskan dan menjelaskan fenomena dalam mobilitasnya karena adanya hubungan antara manusia di tengah kehidupan masyarakat. ${ }^{8}$

Dari pendefinisian ini, sejarah sebagai sebuah pendekatan atau pendekatan historis tidak bisa terlepas dari kajian peristiwa yang melalui dimensi ruang dan waktu.

Jika menariknya dalam konteks Islam, menurut Lokatos, maka apa yang dimaksud dengan Islam Historis sesungguhnya sebuah protective belt yakni domain utama dari apa yang disebut ilmu, sistem pengetahuan yang secara langsung bisa dinilai, diuji ulang, diteliti, dipertnyakan, diformulasi ulang, dan dibangun kembali. Dari sini, Islam historis terlepas dari wilayahnya sebagai Islam normatif.' Islam tidak lagi dikaji pada aspek normatifnya, melainkan wujudnya ketika

${ }^{6}$ Dedi Supriyadi, Kata Pengantar Nurol Aen (Guru Besar Hukum Islam Fakultas Syariah dan Hukum), h.5

8 Dudung Abdurahman (ed.), Metodologi Penelitian Agama: Pendekatan Multidisipliner (Jakarta: Bina Ilmu, 2005), h. 42.

9 Amin Abdullah, Islamic Studiaes (Yogyakarta: Pustaka Pelajar, 2012), h. 52 
hidup di tengah masyarakat, tempat, kondisi sosial, ekonomi, atau bahkan kondisi politik. Hal ini pula yang mengantarkan pendekatan historis mau tidak mau berhubungan dengan sejarah sebagai koreksi atas fatkta. Hal yang perlu digarisbawahi adalah bahwa sejarah disini bukanlah merupakan sejarah naratif, namun sejarah kritis yang tidak hanya melibatkan deskripsi namun juga analisis motif dan kritik data.

Dalam suatu penelitian, aspek historis bisa ditempatkan pada dua posisi yakni ia sebagai objek kajian dan ia sebagai alat bantu untuk mengkaji dalam arti sebuah bagian dari metode penelitian. Di sinilah aspek penting yang harus ditentukan tentang apakah ia merupakan sebuah pengetahuan atau ia sebagai sebuah pendekatan. Konsekuensi pendekatan historis dalam penelitian terhadap gejalagejala atas fenomena yang terjadi mengharuskan untuk mempertimbangkan beberapa aspek, di antara aspek tersebut adalah segi-segi prosessual, perubahan-perubahan, dan aspek diakronis. Lebih dari itu pendekatan historis tidak hanya digunakan untuk melihat pertumbuhan, perkembangan, dan kronologis peristiwa masa lampau, namun juga digunakan untuk mengenal gejala-gejala structural, faktor-faktor kausal, kondisional, kontekstual serta unsurunsur yang merupakan komponen dan eksponen dari proses sejarah yang dikaji. ${ }^{10}$

Mircae Eliade and Joseph M. Kitagawa (12-13) berpendapat bahwa, pendekatan sejarah merupakan metode dan instrument penting bagi penelitian agama. Kajian sejarah (historis) di zaman modern, sepertinya halnya di Abad Pertengahan, menekankan penilaian yang kritis atas sumber-sumber sejarah para sejarawan. Akan tetapi, pada abad kesembilan belas, penelitian agama melalui pendekatan sejarah menekankan agama ummat manusia secara keseluruhan. Oleh karena itu, sejarah agamapun secara khusus mempunyai perhatian (concern) terhadap rekonstruksi yang kritis atas aspek-aspek esensial berbagai agama timur. Perkembangan studi agama dengan pendekatan sejarah telah menarik minat pengkajian agama melalui perbandingan agama. Persoalan yang ditimbulkan oleh pendekatan sejarah adalah perbedaan antara fakta dengan nilai (fact and value). Akan tetapi, akhirnya sejarah harus berbicara atas dasar

10 Dudung Abdurahman (ed.), Metodologi Penelitian Agama: Pendekatan Multidisipliner ..., hlm. 40. 
fakta. Jika demikian, pendekatan sejarah memerlukan metode maupun tujuan yang factual yang hanya mungkin dilakukan dengan menggunakan ilmu-ilmu sosial. ${ }^{11}$

Joachim Wach memberi contoh bahwa penelitian agama dengan pendekatan sejarah seringkali menjadi berfaidah jika, dilakukan dengan cara meminjam metode maupun prosedur dalam lapangan lain. Studi Vinogradoff dibidang hukum dan institusi-institusi, misalnya mempunyai nilai yang besar. Dia menggambarkan metode tersebut sebagai berikut: "Ketika kita menempatkan fakta-fakta dan doktrin-doktrin dalam tatanan ideologis, tak sedikitpun kita bermaksud mengingkari atau menghilangkan kondisi-kondisi geografis, etnologis, politik dan cultural yang memang ikut menentukan perjalanan peristiwa-peristiwa actual." Hal ini secara definitive menuntut kita untuk melakukan sistematikasi dan studi fenomenologis terhadap kondisi sosio-religius. Vinogradoff juga menekankan pentingnya penyempurnaan pandangan yang statis dalm bentuk "typical theory" (tentang jurisprudensi) yang dinamik. "It is not easy" (tidaklah mudah) demikian menurut Vinogradoff. Tujuan esensialnya adalah untuk mengenal nilai-nilai pada tipe-tipe historis sebagai dasar suatu teori hukum. Kita tidak akan berhasil menjelaskan dan menganalisis tipe-tipe kelompok keagamaan yang memiliki motivasi untuk berkelompok dalam kelompok keagamaan tanpa materi yang disajikan oleh sejarah agama kepada kita. ${ }^{12}$

Menurut Sumadi Suryabrata penelitian historis (bistorical research) ini memiliki ciri-cirinya yaitu: (1) Bergantung kepada daya yang diobservasi oleh peneliti itu sendiri; (2) Harus tertib, ketat, sistematik, tuntas, dan buka sekadar mengoleksi informasi yang tidak layak, tidak reliable, dan berat sebelah; (3) Bergantung pada data primer dan sekunder; (4) Harus melakukan kritik eksternal dan internal. ${ }^{13}$

Selain dicirikan dengan kajian menadalam atas pertanyaanpertanyaan dasar yang berhubungan dengan realitas yang secara sederhana diwakili dengan pertanyaan-pertanyaan seperti siapa, apa,

${ }^{11}$ Juhaya S. Praja, Filsafat dan Metodologi Ilmu dalam Islam dan Penerapannya di Indonesia, (Jakarta, Teraju, 2002), h. .47-48

${ }^{12}$ Ibid., h. 48

${ }^{13}$ M.Yatimin Abdullah, Op. Cit., h. .221-222 
mengapa, di mana, kapan, dan bagaimana, pendekatan historis juga memperhatikan metode penelusuran dalam menjawab pertanyaanpertanyaan tersebut tidakhanya secara deskriptif naratif, namun lebih berusaha menjawabnya secara kritis analitis, sehingga apa yang dilakukan pendekatan ini tidak hanya menyajikan wacana naratif namun bertujuan untuk menganalisa alasan, motif dan berbagai hal yang ada dibalik sebuah peristiwa. Aspek penting lainnya dalam pendekatan ini juga adalah kerangka analisis dalam meneropong peritiwa masa lampau yang di awali dengan permasalahan (problemoriented $).{ }^{14}$

Pendekatan historis yang diterapkan pada sebuah riset memungkinkan terhadap dua sifat penelitian, pertama adalah subjektif, yakni hasil penulisan sejarah yang tercampuri oleh pra pengetahuan, gaya, dan struktur pemikiran peneliti. Kedua adalah sifat objektif, yakni hasil penelitian yang berusaha mengungkap data sebagaimana adanya data tersebut dapat mengarahkan pada fakta yang objektif. Dari sini, hal yang perlu diperhatikan adalah perbedaan antara data dan fakta. Perbedaan ini penting, berbeda dengan fakta, data merupakan bahan-bahan mentah yang masih membutuhkan proses analisis. ${ }^{15}$

\section{Pendekatan Sosial Ekonomi}

Kajian sosial ekonomi tentang agama dan perkembangan ekonomi selama ini menggunakan dua pendekatan: pertama, kepercayaan sekte atau golongan agama dan pada karakteristik moral, serta motivasi yang ditimbulkannya. Kedua, perubahan-perubahan sosial dan ekonomi yang mempengaruhi suatu kelompok dan gerakan keagamaan yang muncul sebagai reaksi terhadap perubahan. Walaupun demikian, kedua pendapat tersebut saling menyempurnakan antara satu sisi dengan sisi yang lain. ${ }^{16}$

Analisis yang menarik tentang hubungan agama dengan pengembangan ekonomi oleh $\mathrm{H}$. Palanca, dapat dijadikan kajian

${ }^{14}$ Dudung Abdurahman (ed.), Op. Cit., 42.

15Ibid., h. 43

16Zulfi Mubaraq, Sosiologi Agama, (Malang: UIN Maliki Press,2010), h. 81. Lihat Ishomuddin, Pengantar Sosiologi Agama (Jakarta: PT. Ghalia Indonesia-UMM Press, 2002), h. 80. 
dalam upaya mencoba memahami peran yang dijalankan agama di dalam masyarakat. Dengan cara pandang positivistik, tidak ada cara untuk memaksakan etika agama agar tidak dipatuhi oleh pemeluknya. Di samping itu di sebagian besar di dunia, dengan menurunnya peran agama dalam masyarakat dewasa ini, kita tidak mungkin dapat berharap suatu etika agama memainkan peranan, seperti pada masa pertengahan dan zaman reformasi.Agama dapat disebut sebagai suatu faktor, bukan penyebab pertumbuhan ekonomi. Hubungan agama dengan pembangunan sosial ekonomi bukanlah hubungan kuasalitas, namun hubungan timbal balik. Agama merupakan salah satu faktor yang mendorong pertumbuhan ekonomi, perubahan struktur ekonomi dan kemajuan masyarakat.

Di pihak lain, agama juga tidak statis melainkan berubah mengikuti pertukaran waktu dan perubahan zaman, serta oleh perkembangan dan pertumbuhan ekonomi. Kondisi sosial dan ekonomi ikut mempengaruhi keberadaan agama. Di dalam masyarakat tradisional, agama berfungsi untuk mendorong manusia untuk terlibat dalam peran-peran dan tingkah laku ekonomi, karena agama dapat mengurangi rasa cemas dan takut.Studi yang dilakukan oleh Malinowski di kalangan masyarakat Trobriand, ditemukan bahwa masyarakat tersebut selalumengadakan upacara ritual sebelum melakukan kegiatan mencari ikan di laut. ${ }^{17}$

Agama juga berfungsi menciptakan norma-norma sosial yang mempengaruhi ekonomi.Studi yang dilakukan max Weber tentang "Etika Protestan" menemukan bahwa agama Protestan ternyata memberikan sumbangan tidak kecil terhadap upaya menciptakan jiwa kewirausahaan (spirit of enterprenuership). Ajaran agama tersebut menganjurkan kepada pemeluknya agar selalu bekerja keras, tahan cobaan, dan hidup hemat. Menurt Weber, menjadikan mereka tidak konsumtif, namun selalu berusaha menginvestasikan sumber dana yang dimilikinya untuk berusaha tiada henti dan putus asa. ${ }^{18}$

Sikap rakus yang tidak terbatas karena belum memperoleh keuntungan, tidaklah identik sedikitpun dengan kapitalisme dan

17 Zulfi Mubaraq, Sosiologi Agama, (Malang: UIN Maliki Press,2010), h. 44

${ }_{18}$ Kiki Muhamad Hakiki dan Zaenal Muttaqien, Konflik dan Integrasi Sosial (Telaah Buku A. Malik MTT berjudul 'Pura dan Masjid; Konflik dan Integrasi Pada Suku Tengger Jawa Timur), Al-AdYaN/Vol. IX, N0. 2/Juli-Desember/2014, h. 45 
malahan bukan semangatnya.Kapitalisme bahkan mungkin identik dengan pengendalian dan pengekangan, atau setidak-tidaknya identik dengan suatu watak rasional, dari suatu keinginan-keinginan rasional.Akan tetapi kapitalisme secara pasti identi dengan pencarian keuntungan (profit) dan keuntungan yang dapat diperbaharui untuk selamanya dengan usaha-usaha kapitalis yang rasional dan dilakukan secara terus-menerus. Karena memang demikian seharusnya dalam suatu tatanan masyarakat kapitalis secara keseluruhan, suatu usaha kapitalis individual yang tidak memanfaatkan kesempatan yang ada untuk mengambil keuntungan, pasti akan mengalami malapetaka, yaitu kehancuran.

Pandangan Weber tentang hal ini, adalah bahwa penolakan terhadap tradisi, atau perubahan yang cepat dalam metode dan evaluasi terhadap kegiatan ekonomi, tidak akan mungkin terjadi tanpa dorongan moral dan agama. Namun, dia juga mengajukan bukti bahwa tetap terjadi perbedaan dalam cara yang ditempuh oleh berbagai kelompok keagamaan untuk ikut ambil bagian dalam kapitalisme yang mapan pada masanya sendiri. Sedangkan di dalam masyarakat modern, peran agama terhadap kegiatan ekonomi relatif berkurang. Ekonomi umumnya menekankan pentingnya rasionalitas dan sekularisme, seringkali menyebabkan harus berbenturan kepentingan dengan agama yang menekankan kepercayaan kepada hal-hal yang supranatural.Dengan demikian, keberadaan (existence) agama relatif terpisah dari ekonomi. ${ }^{19}$

Perbedaan yang tajam, tampak pada jika agama dihubungkan dengan lembaga-lembaga yang melaksanakan aktivitas ekonomi.Dalam tindakan ekonomi (produksi dan pertukaran komoditi), nilai-nilai yang kurang tinggi dipraktikkan dan hubungan personal yang kurang dikembangkan.Apalagi nilai-nilai yang dilibatkan bersifat boros (consumatory atau instrumental), mereka hanya berhubungan dengan benda-benda yang dikonsumsi atau dipergunakan.Dengan demikian aktivitas ekonomi lebih bersifat secular atau profaneketimbang sacral. Pada akhirnya, nilai dan tata cara kehidupan ekonomi tampaknya berdasarkan atas asumsi-asumsi yang lebih mudah diuji dalam pengalaman empiris, lebih siap dijalani dan lebih mudah dipastikan sekarang atau nanti. Dalam hal ini,

${ }^{19}$ IIbid., h. 48 
ekonomi dapat juga diarahkan kearah kebenaran karena jika dihubungkan dengan agama maka aktivitas ekonomi juga dapat menjadi sesuatu hal yang bersifat saktal.

Pengaruh agama terhadap golongan masyarakat pun jika dilihat dari karakter masing-masing golongan pekerjaan tidak akan berbeda jauh dengan pengaruh agama terhadap ekonomi. Golongan masyarakat tersebut adalah sebagai berikut: pertama, golongan petani. Mereka adalah masyarakat yang terbelakang, di daerah trisolasi, system masyarakatnya sederhana. Di samping itu, terdapat sumber ketidakpastian, ketidakmampuan, mata pencaharian tergantung pada alam, serangan hama yang di luar kemampuan petani. Oleh karena itu, mereka mencari kekuatan di luar dirinya yang dianggap dapat mengatasinya persoalan itu.Misalnya, diadakannya upacara tolak balak dengan menyediakan sesajen untuk Dewi Sri.Hal ini menunjukkan pengaruh agama begitu kuat terhadap ekonomi golongan petani sehingga menyebabkan jiwa keagamaan mereka lebih dekat dengan alam.Kedua, golongan nelayan.Golongan ini tidak jauh karakternya dengan petani.Mata pencahariannya tergantung pada alam, musim, adanya badai, dan juga hal-hal yang di luar kemampuan mereka.Oleh karena itu, merekapun mengadakan upacara untuk penguasa laut, Nyi Roro Kidul.Ketiga, pengrajin dan pedagang kecil.Mata pencaharian mereka didasarkan atas landasan ekonomi yang memerlukan perhitungan rasional.Namun, dalam hal kelahiran, perkawinan dan kematian masih diliputi perasaan keagamaan yang kental, sehingga merekapun tetap mengadakan upacara keagamaan.Keempat, pedagang besar.Mata pencaharian mereka lebih berorientasi pada kehidupan duniawi, semakin besar penghasilan dan kekayaan yang diperoleh, maka semakin kecil kecenderungan mereka terhadap agama. Namun, mereka tetap melakukan sumbangan dana untuk kepentingan agama untuk mewakili perasaan keagamaannya. Kelima, karyawan.Golongan ini disebut juga golongan demokrat atau kalangan industri, karena sistem sosialnya bersifat modern.Mata pencahariannya berdasarkan penalaran dan efisiensi, sehingga kecenderungan rasa keagamaan mereka bersifat serba mencari untung dan enak, karena gaji telah diterima setiap bulan. Dalam menghadapi masalah "kelangkaan" dalam arti kesejahteraan material (ekonomi)berlawanan dengan penglihatan Karl Marx-Weber melihat bahwa agama memberikan saham yang tidak kecil serta amat positif. Sebagai 
contohnya ialah bahwa Protestantisme memberikan pengaruh kausal yang kuat kepada lahir dan berkembangnya kapitalisme modern.Pendapatnya itu dipaparkan dalam bukunya "The Protestant Ethic and the Spirit of Capitalism".

Di Indonesia, kenyataan menunjukkan bahwa pengembangan ekonomi Islam dimulai melalui pola kedua sehingga tidak heran jika pengembangan industri keuangan syariah tumbuh lebih cepat dibandingkan pengkajian teoritis dan konseptual dalam pembentukan sistem yang lebih komprehensif. Maka, wajar masih adanya keterbatasan sumber daya insani yang memilih pemahaman secara baik aspek ekonomi dan syariah. Hal ini menjadi tantangan yang harus dihadapi dalam rangka pengembangan ekonomi Islam. Keterangan-keterangan ilmiah yang dihasilkan sosiologi agama tidak akan menyelesaikan segala kesulitan secara tuntas. Segi kesulitan yang bukan sosiologis harus dimintakan resep dari ilmu yang bersangkutan. Misalnya teknologi, ekonomi, demigrafi dlsb. Jika yang dimaksud moralitas kehidupan itu merupakan wilayah ekonomi, maka moral ekonomi inilah yang perlu kita pikirkan secara kritis agar bisa menghasilkan moralitas yang bermakna bagi kehidupan. Kalau kita kaitkan dengan konteks Indonesia dewasa ini yang tengah mengacu pembangunan ekonomi tetapi justru masih banyak pelanggaran moral yang berakibat merugikan keuangan negara. Anehnya pelanggaran itu terus berkelanjutan dengan pelaku banyak dari kalangan intelektual dan borokrat yang seharusnya menjadi uswah bagi masyarakat.

\section{E. Penutup}

Demikian tiga pendekatan pemikiran keagamaan kontemporer yang dideskripsikan di atas. Masing-masing pendekatan memiliki ciri khas, kelebihan dan kekuarangnnya masing-masing. Pendekatan normativitas lebih konsen pada studi teks yang normatif, bersifat kaku dan menjunjung tinggi norma-norma serta nilai-nilai. Sementara pendekatan sejarah menawarkan aspek kesejarahan dalam menilai dan memahami teks dan konteks sehingga pemikiran keagamaan terus dapat diperbaharui seiring perkembangan zaman. Sementara pendekatan sosial ekonomi lebih fokus pada gejala 
kemasyarakat dalam hubungannya dengan sistem ekonomi yang dianut oleh suatu masyarakat.

Islam memiliki pandangan sosial ekonomi sendiri. Tidak diragukan lagi bahwa legalitas bisnis dibahas oleh Al- Qur'an. Eksposisi sintetik ajaran Al- Qur'an diharapkan akan membantu kita dalam menggambarkan prinsip-prinsip dasar dari etika bisnis AlQur'an. Ketaatan pada prinsip-prinsip ini akan memberikan jaminan keadilan dan keseimbangan yang dibutuhkan dalam bisnis dan akan menjaga aktivitas komersial pada koridor yang benar.[26] Menurut Qardhawi poros risalah nubuwah Nabi Muhammad SAW adalah akhlak. Karena itu Islam telah mengimplikasikan antara mu'amalah dengan akhlak, seperti jujur, amanah, adil, ihsan, berbuat kebaikan, silaturahmi, dan sayang-menyayangi. Dikaitkan akhlak pada aspek hidup menyeluruh, sehingga tidak ada pemisahan antara ilmu dengan akhlak, antara politik dengan akhlak, antara ekonomi dengan akhlak, dan perang dengan akhlak, dan lain sebagainya. Dengan demikian, akhlak menjadi daging dan urat nadi kehidupan Islam yang harus memandu segala aktivitas seorang Muslim. Jika kita berbicara tentang akhlak dalam ekonomi Islam, maka tampak secara jelas di hadapan kita empat nilai utama, yaitu: rubbaniyyah (ketuhanan),akhlak, kemanusian, dan pertengahan. Nilai-nilai ini memancarkan keunikan dalam ekonomi Islam yang tidak dimiliki oleh sistem ekonomi manapun di dunia. Nilai-nilai tersebut merupakan karakteristik syariat Islam yang kaffah, sempurna dalam segala dimensinya. Atas dasar karakteristik itu ekonomi Islam jelas berbeda dengan sistem ekonomi konvensional karena ia adalah sebuah sistem ekonomi alamiah, ekonomi humanistis, ekonomi moralistis, dan ekonomi moderat. Makna dan nilai-nilai pokok yang empat ini mempunyai dampak terhadap seluruh aspek ekonomi, baik dalam masalah produksi, konsumsi, sirkulasi maupun distribusi. Semua itu terpola oleh nilainilai tersebut, karena jika tidak, niscaya ke-islam-an itu hanya sekedar simbol tanpa makna. 


\section{Daftar Pustaka}

Abuddin Nata, Peta Keragaman Pemikiran Islam di Indonesia, Jakarta: PT Raja Grafindo, 2001

Abuddin Nata, Metodologi Studi Islam, Jakarta : PT. Raja Grafindo Persada, 2008

Abdurahman, Dudung. (ed.), Metodologi Penelitian Agama: Pendekatan Multidisipliner, Yogyakarta: Lembaga Penelitian UIN Sunan Kalijaga, 2006

Abdullah, Amin. Islamic Studiaes: Normativitas atau Historisitas, Yogyakarta: Pustaka Pelajar, 2012

Atho Mudzhar, Pendekatan Studi Islam: teori dan Praktek, Yogyakarta: Pustaka Pelajar, 1998

Khoiruddin Nasution,, Pengantar Studi Islam, Yogyakarta: Academia dan Tazzafa, 2009 Imam Suprayogo dan Toroni, Metodologi Penelitian Sosial-Agama, Bandung: Rosda Karya, 2003

Kiki Muhamad Hakiki dan Zaenal Muttaqien, Konflik dan Integrasi Sosial (Telaab Buku A. Malik MTT berjudul "Pura dan Masjid; Konflik dan Integrasi Pada Suku Tengger Jawa Timur), AlAdYaN/Vol. IX, N0. 2/Juli-Desember/2014. 